\author{
N. V. Kosova, O. A. Podgornova \\ Institute of Solid State Chemistry and \\ Mechanochemistry SB RAS, \\ Kutateladze 18, 630128 Novosibirsk, Russia \\ Tel: +7 $3832332410^{\star} 1115$ \\ Fax: +7383 3322847 \\ E-mail: kosova@solid.nsc.ru
}

\title{
Supervalent doping of $\mathrm{LiFePO}_{4}$ for enhanced electrochemical performance*
}

Vanadium and titanium doped orthophosphates $\mathrm{LiFe}_{0.9} \mathrm{M}_{0.1} \mathrm{PO}_{4}$ with an olivinetype structure (space group Pnma) were prepared by mechanochemically assisted solid state synthesis using a high-energy AG0-2 planetary mill and post-annealing at $750{ }^{\circ} \mathrm{C}$. It has been established that the $\mathrm{V}$ and $\mathrm{Ti}$ ions do not fully substitute for $\mathrm{Fe}^{2+}$ in the $\mathrm{LiFePO}_{4}$ structure. The other part of these ions participate in the formation of the secondary phases with the open Nasicon-type structures: monoclinic $\mathrm{Li}_{3} \mathrm{~V}_{2}\left(\mathrm{PO}_{4}\right)_{3}$ (space group $P 2_{1} / n$ ) and rhombohedral $\mathrm{LiTi}_{2}\left(\mathrm{PO}_{4}\right)_{3}$ (space group $R-3 \mathrm{C})$. According to TEM, the average particle size of the nanocomposites is about 100-300 nm. EDX microanalysis reveals that the small particles of the secondary phases are segregated on the surface of the larger $\mathrm{LiFePO}_{4}$ particles. On the charge-discharge profiles of LiFe0.9M0.1P04, the plateaus corresponding to $\mathrm{LiFePO}_{4}$ and the secondary phases are observed. $\mathrm{V}$ doping improves cycleability and rate capability of $\mathrm{LiFePO}_{4}$ to a greater extent than Ti.

Keywords: $\mathrm{LiFePO}_{4}$; supervalent doping; mechanical activation; electrochemical cycling

*This work is executed at partial financial support of RFBR (grant № 14-03-01082).

(C) Kosova N. V., Podgornova 0. A., 2015

\section{Introduction}

Many efforts have been made to turn insulating compounds into attractive electrode materials, including nanosizing, carbon nanopainting and metal doping [1-3]. This allows the olivine-type lithium iron phosphate $\mathrm{LiFePO}_{4}$ with inherent low electronic conductivity and slow lithium diffusion [3,4] to become a promising cathode material exhibiting favorable electrochemical properties and to be commercialized. Li ions migration in $\mathrm{LiFePO}_{4}$

is found to occur preferably down the [010] channels, following a curved trajectory. The most favorable intrinsic defects in $\mathrm{LiFePO}_{4}$ are the cation antisite defects, in which $\mathrm{Li}$ and $\mathrm{Fe}$ ions exchange positions. According to $a b$ initio simulations of the $\mathrm{LiFePO}_{4}$ doping, low favorable energies are found only for divalent dopants on the Fe sites, whereas substitution energy for supervalent cations is energetically unfavorable [5]. Meanwhile, it has been 
shown experimentally that supervalent doping of $\mathrm{LiFePO}_{4}$ on $\mathrm{Li}$ sites increases its electronic conductivity by a factor of $\sim 108$ and results in superior electrochemical performance [3]. Later on, these results were explained by the formation of the conductive impurity phases. The studies on the enhancement of life stability and rate capability of $\mathrm{LiFePO}_{4}$ are still highlighted.

Vanadium and titanium are very attractive dopants for $\mathrm{LiFePO}_{4}$ since they readily form corresponding lithium metal phosphates. Although several reports have been published on vanadium [6-12] and titanium [13-16] substitution, there is much disagreement regarding the formation of the $\mathrm{LiFe}_{1-\mathrm{y}} \mathrm{V}_{\mathrm{y}} \mathrm{PO}_{4}$ and $\mathrm{LiFe}_{1-\mathrm{y}} \mathrm{Ti}_{\mathrm{y}} \mathrm{PO}_{4}$ solid solutions. Some authors insist that $\mathrm{V}^{3+}$ substitutes for $\mathrm{Fe}^{2+}$ on $\mathrm{Fe}$ sites within the solid solubility limit $0<\mathrm{X}<0.08$ [9] or at $x<0.1$ [7]. According to [7], the solidsolution limit depends on the preparation method and heat-treatment temperature. When synthesis temperature is increased to $700{ }^{\circ} \mathrm{C}$, the decreased $\mathrm{V}$ solubility and the formation of the second phase $\mathrm{Li}_{3} \mathrm{~V}_{2}\left(\mathrm{PO}_{4}\right)_{3}$ - are observed. Similarly, when $\mathrm{LiFePO} 4$ was doped with $\mathrm{Ti}$, titani- um phosphate impurities like $\operatorname{TiP}_{2} \mathrm{O}_{7}$ and $\mathrm{LiTi}_{2}\left(\mathrm{PO}_{4}\right)_{3}$ at higher doping level $(\mathrm{y}>0.05)$ were formed [14]. V- and Ti-doped LiFe$\mathrm{PO}_{4}$ samples are reported to show excellent reversible capacity and rate capability. However, there is no common viewpoint on the mechanism of the improvement. In many previous studies, cationic substitution to the Fe site (M2 site) in $\mathrm{LiFePO}_{4}$ usually results in higher ionic mobility and $\mathrm{Li}_{+}$diffusion coefficient due to the cell volume expansion and the probable weakening of the $\mathrm{Li}-\mathrm{O}$ interactions. The latter lowers the charge transfer resistance and thus improves the reversibility of the lithiation process. Only a limited number of reports show that cationic substitution to the Li site (M1 site) is probable, resulting in the production of $\mathrm{Li}$ vacancies that increases the capacity of LiFePO4 [11]. It remains essential to develop the synthetic routs with an appropriate cation doping of $\mathrm{LiFePO}_{4}$ along with decreased particle size and optimized carbon coating.

The aim of the present work was the study of $\mathrm{V}$ - and Ti-doping of $\mathrm{LiFePO}_{4}$ prepared by mechanochemically assisted carbothermal reduction.

\section{Experimental}

$\mathrm{Li}_{2} \mathrm{CO}_{3}, \quad \mathrm{Fe}_{2} \mathrm{O}_{3}, \quad \mathrm{~V}_{2} \mathrm{O}_{5}, \quad \mathrm{TiO}_{2}$ and $\left(\mathrm{NH}_{4}\right)_{2} \mathrm{HPO}_{4}$ were used as reagents for the synthesis of $\mathrm{LiFe}_{0.9} \mathrm{~V}_{0.1} \mathrm{PO}_{4}$ and $\mathrm{LiFe}_{0.9} \mathrm{Ti}_{0.1} \mathrm{PO}_{4}$, further labeled as LFVP and LFTP. Soot was used as a reducing and coating agent (5\%). The reagent mixtures were undergone a mechanochemical activation (MA) by means of a highenergy AGO-2 planetary mill (900 rpm). The activated mixtures were annealed at $750{ }^{\circ} \mathrm{C}$ in Ar flow.
X-Ray powder diffraction (XRD) was performed using D8 Advance Bruker diffractometer, $\mathrm{CuKa}$ irradiation. The structural refinement of the XRD data was carried out by the Rietveld method using the GSAS software package. Particle size and morphology were characterized by transmission electron microscopy (TEM) using a JEM-2200 FS transmission electron microscope. Microanalysis was performed by means of energy dispersive X-ray analyzer EX-230 BU. For electrochemical testing, 
the composite cathodes were fabricated using $75 \mathrm{wt} . \%$ active material, $20 \mathrm{wt} . \%$ Super $\mathrm{P}$ (conductive carbon) and 5 wt.\% PVDF/ NMP binder. The as-mixed slurry was then pasted on the aluminum foil to obtain working electrodes. The loading density of the prepared samples was $2-3 \mathrm{mg} \cdot \mathrm{cm}^{-2}$, and the electrode diameter of $10 \mathrm{~mm}$ was used

\section{Results and discussion}

Figure 1 shows the Rietveld refined $\mathrm{XRD}$ patterns of the as-prepared samples LFVP and LFTP. It is evident that both of them are well fitted by a two-phase model: LFP with an orthorhombic olivine-type structure (space group Pnmb) and LVP with a monoclinic structure (space group $\left.P 2_{1} / n\right)$ or LTP with a rhombohedral structure (space group $R-3 \mathrm{c}$ ). The observed and calculated patterns match well, and the reliability factor $\left(R_{w}\right)$ is good. The olivine structure of LFP consists of corner-shared FeO6 octahedra running parallel to the $b$-axis, which are linked together by the $\mathrm{PO}_{4}$ tetrahedra. The monoclinic structure of LVP comprised of metal octahedra and phosphate tetrahedra sharing oxygen vertices. $\mathrm{Li}$ ions are situated in the cavities within the framework [17]. The occurrence of corner-shared chains of Li polyhedra along the b-axis and open diffusion pathways in the other directions provide rapid, isotropic ionic transport similar to the fast-ion conduction in NASICON phases. The rhombohedral structure of LTP consists of a three-dimensional network made of $\mathrm{TiO}_{6}$ octahedra sharing all their corners with $\mathrm{PO}_{4}$ tetrahedra and vice versa to form so-called 'lantern units', all oriented in the same direction (along the c-axis) [18]. The conduction channels are generated along the $\mathrm{c}$-axis direction. The results of structural analysis of the com- throughout. The working electrodes were dried at $120^{\circ} \mathrm{C}$. Swagelok-type cells were assembled in an argon-filled glove box with $\mathrm{Li}$ as an anode, $1 \mathrm{M} \mathrm{LiPF}_{6}$ solution in a mixture of ethylene carbonate and dimethylcarbonate (1:1 by weight) as an electrolyte, and a glass fiber filter (Whatman, Grade $\mathrm{GF} / \mathrm{C}$ ) as a separator. posites obtained from XRD Rietveld refinement are shown in Table 1. The lattice parameters of LFP in the LFVP composite are slightly smaller than those of pure LFP. The slight changes of lattice parameters can be ascribed to the small incorporation of $\mathrm{V}$ ions with smaller ionic radius $\left(\mathrm{R}_{\mathrm{V} 3+}=0.64 \AA, \mathrm{R}_{\mathrm{V} 4+}=0.53 \AA\right.$ ) into the structure of LFP. The calculated mol.\% of LFP and LVP phases are about 96.3 and 3.7 mol.\%, respectively. In the LFTP composite, the changes of lattice parameters
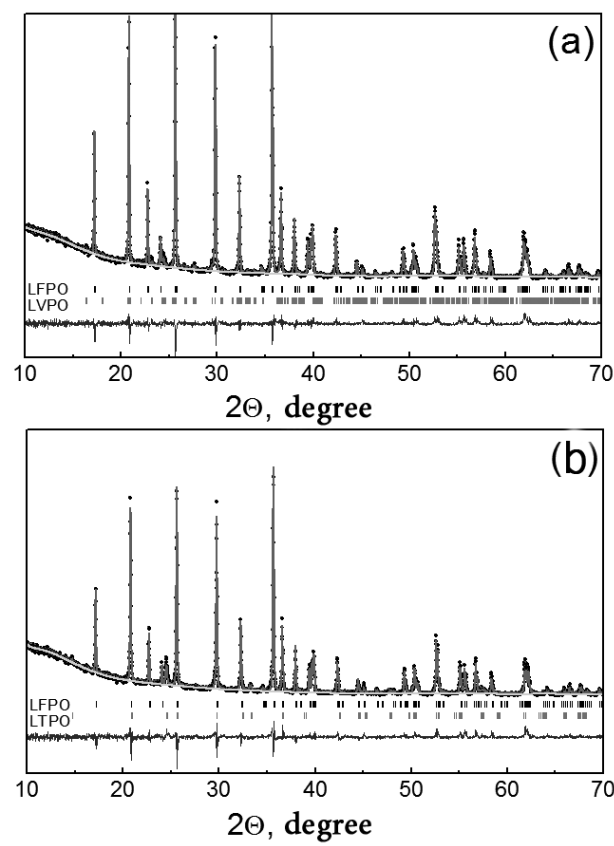

Fig. 1. Rietveld refined XRD patterns o f V- (a) and Ti-doped (b) $\mathrm{LiFePO}_{4}$ 
Table 1

Results of structural analysis obtained from XRD Rietveld refinement

\begin{tabular}{c|c|c|c|c|c}
\multirow{2}{*}{ Lattice parameters } & \multirow{2}{*}{ LFP } & \multicolumn{2}{|c|}{ LFVP } & \multicolumn{2}{c}{ LFTP } \\
\cline { 3 - 6 } & & LFP & LVP & LFP & LTP \\
\hline$a, \AA$ & $10.3052(1)$ & $10.2935(3)$ & $8.583(6)$ & $10.3053(3)$ & $8.491(2)$ \\
\hline$b, \AA$ & $5.9946(1)$ & $5.9886(1)$ & $8.574(6)$ & $5.9947(2)$ & $8.491(2)$ \\
\hline$c, \AA$ & $4.6833(1)$ & $4.6843(1)$ & $12.018(8)$ & $4.6828(1)$ & $20.855(9)$ \\
\hline$\square$ & & & $90.56(6)$ & & \\
\hline$V, \AA^{3}$ & $289.32(1)$ & 288.76 & $884.4(7)$ & $289.29(2)$ & $1302.1(4)$ \\
\hline$R_{\mathrm{wp}} \%$ & 6.60 & \multicolumn{2}{|c}{8.52} & \multicolumn{2}{c}{9.29} \\
\hline$\chi^{2}$ & 1.290 & \multicolumn{2}{|c|}{2.205} & \multicolumn{2}{c}{2.214} \\
\hline LFP/LMP (mol. \%) & & \multicolumn{2}{|c|}{$96.3 / 3.7$} & \multicolumn{2}{c}{$95.8 / 4.2$}
\end{tabular}

of LFP are smaller than in LFVP. The calculated LFP/LTP ratio is 95.8/4.2 mol.\%, evidencing lower degree of $\mathrm{Ti}^{4+} / \mathrm{Fe}^{2+}$ substitution.

Incorporation mechanism of supervalent ions in the structure of LFP is debatable. According to [5], it is unfavorable in all the $\mathrm{LiMPO}_{4}$ systems. This strongly suggests that these ions are unstable within the crystal lattice of $\mathrm{LiMPO}_{4}$ and unlikely to be incorporated beyond low concentration $(>3 \%)$. The compensation mechanism for supervalent dopants was found to be the formation of $\mathrm{M}^{2+}$ vacancies, whereas compensation by a change in charge state of the transition metal ion was much higher in energy.

According to the literature, the electronic state of $\mathrm{Fe}$ ions in LFP does not change upon $\mathrm{V}$ - and Ti-doping. The authors of Refs. [13-15] have found the oxidation state of doped Ti ions as 4+, whereas the oxidation state of $\mathrm{V}$ ions is between $3+$ and 4+ [9-11]. The $\mathrm{M}^{3+}$ and $\mathrm{M}^{4+}$ substitution for $\mathrm{Fe}^{2+}$ in the structure of LFP compound along with the formation of $\mathrm{Li}$ vacancies and 'anti-site' pair defects can be represented by the following equations in Kroger-Vink notation:

$$
\mathrm{Li}_{\mathrm{Li}}{ }^{\mathrm{x}} \rightarrow \mathrm{V}_{\mathrm{Li}}{ }^{\prime}+\mathrm{Li}_{\mathrm{i}} \cdot
$$

$\mathrm{Fe}_{\mathrm{Fe}}{ }^{\mathrm{x}}+\mathrm{Li}_{\mathrm{Li}}{ }^{\mathrm{x}} \rightarrow \mathrm{LiFe}^{\prime}+\mathrm{Fe}_{\mathrm{Li}} \cdot$

$1 / 2 \mathrm{M}_{2} \mathrm{O}_{3}+3 / 2 \mathrm{Fe}_{\mathrm{Fe}}{ }^{\mathrm{x}} \rightarrow \mathrm{M}_{\mathrm{Fe}} \cdot+1 / 2 \mathrm{~V}_{\mathrm{Fe}}{ }^{\prime}+$ $3 / 2 \mathrm{FeO}$

$\mathrm{MO}_{2}+2 \mathrm{Fe}_{\mathrm{Fe}}{ }^{\mathrm{x}} \rightarrow \mathrm{M}_{\mathrm{Fe}}{ }^{\ddot{ }}+\mathrm{V}_{\mathrm{Fe}}{ }^{"}+2 \mathrm{FeO}$

It was supposed that iron ions can migrate from $\mathrm{Fe}_{\mathrm{Li}}$ ' sites to $\mathrm{V}_{\mathrm{Fe}}$ " vacancies. Thus, the main defects in the $\mathrm{V}$ - and $\mathrm{Ti}$ doped LFP should be Li vacancies and $\mathrm{M}^{\mathrm{n}+}$ ions in Fe sites [5].

According to TEM, the LFVP and LFTP samples consist of the irregular shaped nanosized particles with an average particle size of about 100-300 nm similar to pure LFP (Fig. 2). The surface of the particles is coated by a thin carbon layer. EDX microanalysis confirms the targeted concentration of the elements in the as-prepared composites. The maps of Fe and V distribution in LFVP are shown individually and overlaid with the original image in Fig. 2c-e. It is evident that LVP forms smaller particles, preferably on the surface of larger LFP particles, thus, probably enhancing surface Li ion mobility in the composite.

Electrochemical behavior of LFVP and LFTP was studied within the 2.5-4.3 V voltage window at $\mathrm{C} / 10$ charge-discharge rate. Charge-discharge profiles and the correspondent $\mathrm{d} Q / \mathrm{d} V$ vs. voltage plots 
are shown in Fig. 3. The profiles, as well as the number and the position of the redox peaks agree with the literature data for the pure phases. The plateau at around $3.4 \mathrm{~V}$ is based on the $\mathrm{Fe}^{2+} / \mathrm{Fe}^{3+}$ redox couple corresponding to one $\mathrm{Li}$ (de)intercalation from/in LFP via a two-phase mechanism. $\mathrm{V}$-doped sample is characterized by the appearance of some additional distinct plateaus at higher voltage, which have been attributed to the operation of $\mathrm{V} 3+$ / $\mathrm{V}^{4+}$ and $\mathrm{V}^{4+} / \mathrm{V}^{5+}$ couples in LVP. According to Ref. [17], LVP exhibits three oxidation plateaus around 3.62, 3.70, and 4.09 $\mathrm{V}$ when charged to $4.3 \mathrm{~V}$, corresponding to a sequence of two-phase transitions $\mathrm{Li}_{3} \mathrm{~V}_{2}\left(\mathrm{PO}_{4}\right)_{3} \rightarrow \mathrm{Li}_{2.5} \mathrm{~V}_{2}\left(\mathrm{PO}_{4}\right)_{3} \rightarrow \mathrm{Li}_{2} \mathrm{~V}_{2}\left(\mathrm{PO}_{4}\right)_{3}$ $\rightarrow \mathrm{Li}_{1} \mathrm{~V}_{2}\left(\mathrm{PO}_{4}\right)_{3}$. Very close position of the oxidation and reduction peaks for pure LVP upon cycling in the $2.5-4.3 \mathrm{~V}$ points to low degree of polarization and that the electron and ion transport is facile [17]. Ti-doped LFP also exhibits additional plateau, but at lower voltage. This plateau was ascribed to operation of the Ti4+/ Ti3 + couple in LTP. It has been found earlier that LTP can insert two additional Li ions at $\sim 2.5 \mathrm{~V}$ corresponding to reduction of two $\mathrm{Ti}^{4+}$ ions to $\mathrm{Ti}^{3+}$ [19]. Li insertion in LTP is realized by a two-phase mechanism. It should be emphasized that LTP serves as an insertion host to accommodate the Li ions that could not be inserted back into the LFP structure. Note that the position of the redox peaks on the $\mathrm{d} Q / \mathrm{d} V$ plots well corresponds to those of pure LFP, LVP and LTP, evidencing that low degree of substitution and the composite formation do not noticeably influence voltage of the redox processes upon cycling. On the contrary, in the case of the olivine-type solid solutions, e.g., $\mathrm{LiFe}_{1-\mathrm{y}}$ $\mathrm{Mn}_{\mathrm{y}} \mathrm{PO}_{4}$ and $\mathrm{LiFe}_{1-\mathrm{y}} \mathrm{Co}_{\mathrm{y}} \mathrm{PO}_{4}$, the $\mathrm{Fe} 2+/ \mathrm{Fe}^{3+}$
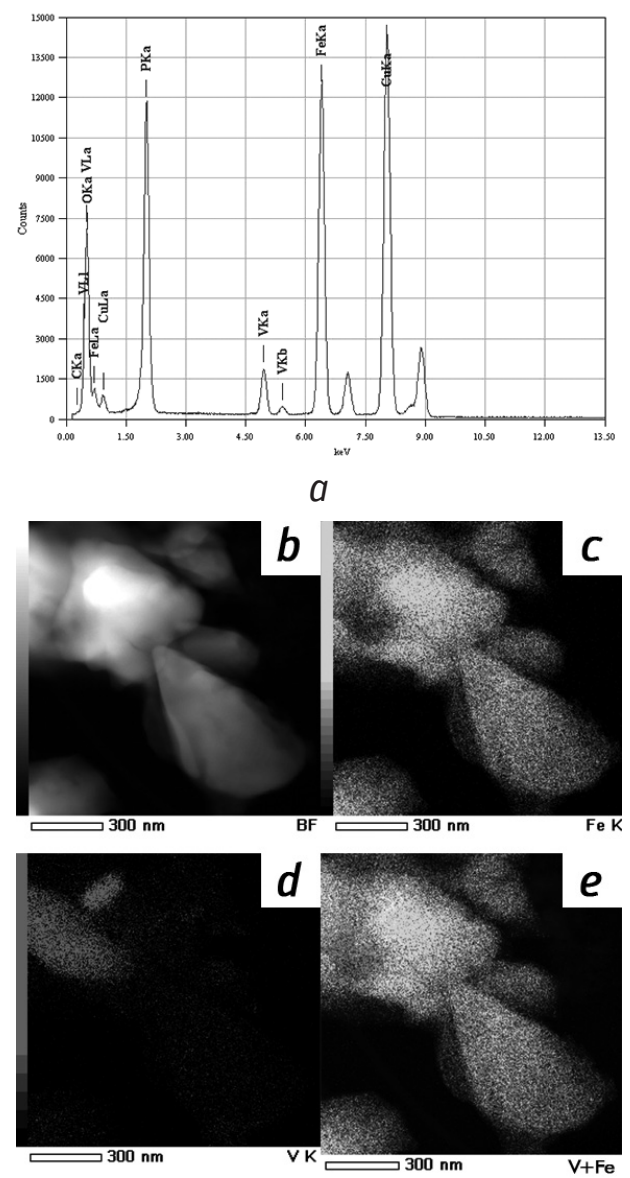

Fig. 2. EDX (a), TEM (b) and element distribution images (c-e) of $\mathrm{V}$-doped $\mathrm{LiFePO}_{4}$.

and $\mathrm{Mn}^{2+} / \mathrm{Mn}^{3+}\left(\mathrm{Co}^{2+} / \mathrm{Co}^{3+}\right)$ redox potentials progressively increase/decrease $v s$. dopant content [20, 21].

Figures $4 \mathrm{a}$ and $4 \mathrm{~b}$ present discharge profiles of the doped samples at different rates, whereas Fig. $4 \mathrm{c}$ and $4 \mathrm{~d}$ display the dependence of the specific discharge capacity vs. cycle number at $\mathrm{C} / 10$ rate and cycling rate, respectively. The initial discharge capacity was $152 \mathrm{mAh} \cdot \mathrm{g}^{-1}$ for LFVP and $135 \mathrm{mAh} \cdot \mathrm{g}^{-1}$ for LFTP, however it gradually decreases at the following cycles. Rate capability of LFVP is superior to that of LFTP. The enhancement of the 

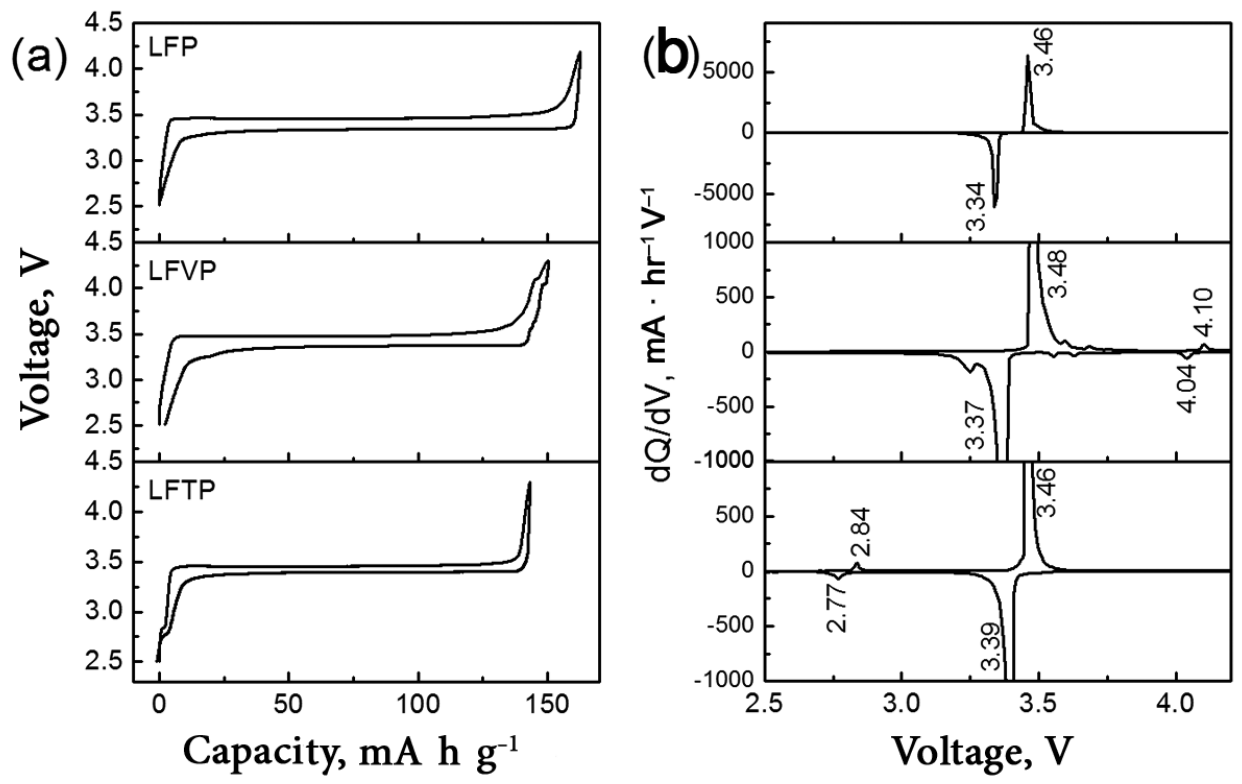

Fig. 3. Charge-discharge profiles (a) and $d Q / d V$ vs. voltage plots (b) for pure, $\mathrm{V}$ - and Ti-doped $\mathrm{LiFePO}_{4}$
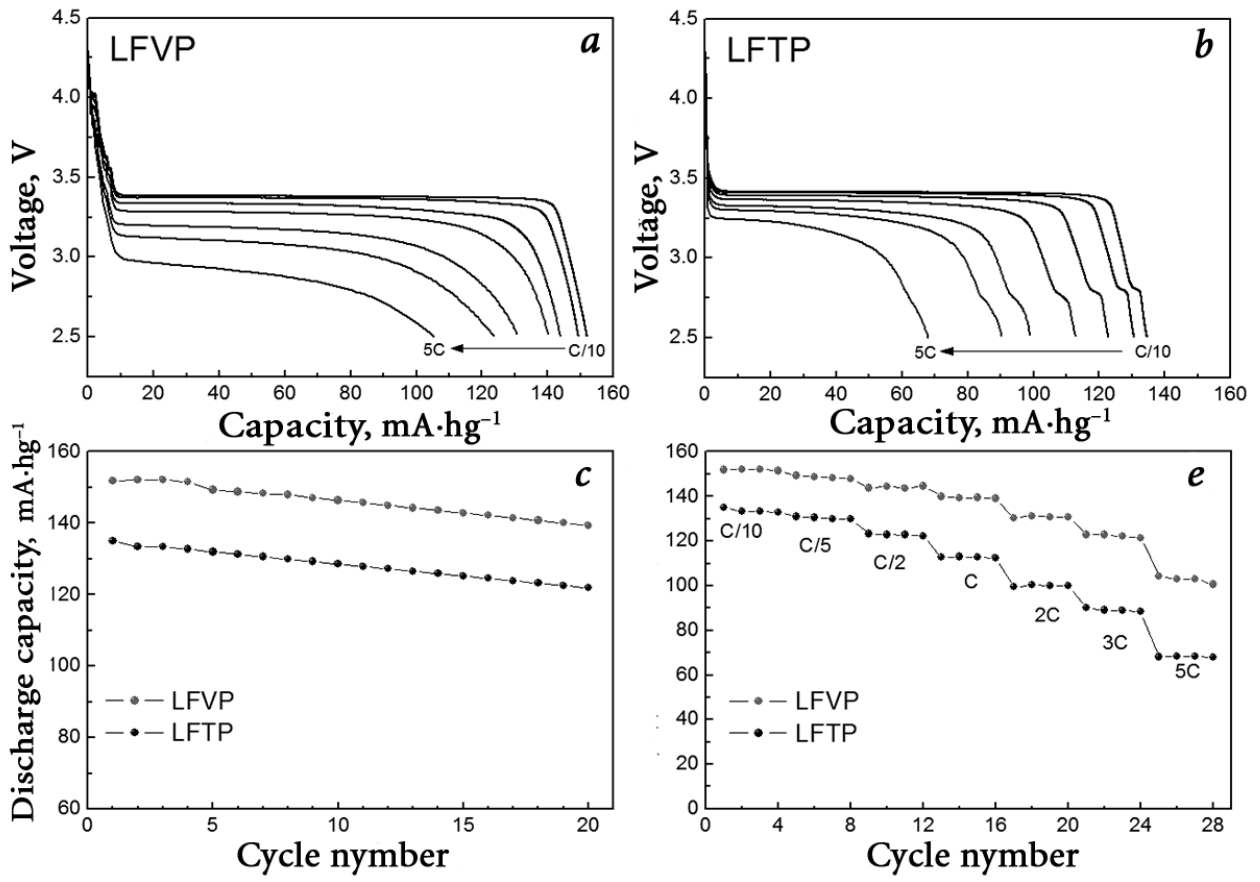

Fig. 4. Discharge profiles (a,b), specific discharge capacity vs. cycle number (c) and cycling rate (d) for $\mathrm{V}$ - and Ti-doped $\mathrm{LiFePO}_{4}$ 
electrochemical performance of LFVP was considered to be a result of the presence of LVP phase with high Li ion mobil- ity and suitable amount of point defects in the structure of LFVP.

\section{Conclusion}

V- and Ti-doped $\mathrm{LiFePO}_{4}$ samples were synthesized using $\mathrm{Fe}_{2} \mathrm{O}_{3}$ and $\mathrm{V}_{2} \mathrm{O}_{5}$ or $\mathrm{TiO}_{2}$ as the raw materials with carbon both as a reductive and covering agent by a simple mechanochemically assisted carbothermal reduction. It has been established that the as-prepared samples are comprised of two finely mixed phases: $\mathrm{LiFePO}_{4}$ with a small degree of $\mathrm{Fe} / \mathrm{V}(\mathrm{Ti})$ substitution and the impurity phases: $\mathrm{Li}_{3} \mathrm{~V}_{2}\left(\mathrm{PO}_{4}\right)_{3}$ or $\mathrm{LiTi}_{2}\left(\mathrm{PO}_{4}\right)_{3}$. Small particles of the secondary phases are segregated on the surface of larger $\mathrm{LiFePO}_{4}$ particles.
V-doped $\mathrm{LiFePO}_{4}$ exhibits better cycleability and rate capability than Ti-doped one. This should be due to higher lithium diffusion arose from the presence of $\mathrm{Li}_{3} \mathrm{~V}_{2}\left(\mathrm{PO}_{4}\right)_{3}$ with high Li ion mobility and suitable amount of defects due to partial $\mathrm{V}$ substitution for Fe. The increase in a number of voltage plateaus and the mean intercalation voltage due to the presence of the $\mathrm{Li}_{3} \mathrm{~V}_{2}\left(\mathrm{PO}_{4}\right)_{3}$ secondary phase should be advantageous for improving the cell performance of $\mathrm{LiFePO}_{4}$.

1. Yamada A., Chung S. C., Hinokuma K. Optimized $\mathrm{LiFePO}_{4}$ for lithium battery cathodes. J. Electrochem. Soc. 2001;148(3):A224-A229.

2. Ravet N., Chouinard Y., Magnan J. F., Besner S., Gauthier M., Armand M. Electroactivity of natural and synthetic triphylite. J. Power Sources. 2001;97-98:503507. doi: 10.1016/S0378-7753(01)00727-3.

3. Chung S. Y., Chiang Y. M. Microscale Measurements of the Electrical Conductivity of Doped $\mathrm{LiFePO}_{4}$. Electrochem. Solid-State Lett. 2003;6(12):A278-A281.doi: 10.1149/1.1621289.

4. Prosini P. P., Lisi M., Zane D., Pasquali M. Determination of the chemical diffusion coefficient of lithium in LiFePO4. Solid State Ionics. 2002;148(1-2):45-51. doi: 10.1016/S0167-2738(02)00134-0.

5. Fisher C. A. J., Prieto V. M. H., Islam M. S. Lithium battery materials $\mathrm{LiMPO}_{4}$ $(\mathrm{M}=\mathrm{Mn}$, transport $\mathrm{Fe}, \mathrm{Co}$, and $\mathrm{Ni})$ : Insights into defect association, mechanisms, and doping behavior.Chem. Mater. 2008;20(18):5907-5915. doi: 10.1021/cm801262x.

6. Wang L., Li Z., Xu H., Zhang K. J. Phys. Chem. C. 2008;112:308.

7. Omenya F., Chernova N. A., Upreti S., Zavalij P. Y., Nam K. W., Yang X. Q., Whittigham M. S. Can vanadium be substituted into $\mathrm{LiFePO}_{4}$ ? Chem. Mater. 2011;23(21):4733-4740. doi: 10.1021/cm2017032.

8. Xiang J. Y., Tu J. P., Zhang L., Wang X. L., Zhou Y., Qiao Y. Q., Lu Y. Improved electrochemical performances of $9 \mathrm{LiFePO}_{4} \cdot \mathrm{Li}_{3} \mathrm{~V}_{2}\left(\mathrm{PO}_{4}\right) / \mathrm{C}$ composite prepared by a simple solid-state method. J. Power Sources. 2010;195(24):8331-8335. doi: 10.1016/j.jpowsour.2010.06.070.

9. Ma J., Li B., Du H., Xu C., Kang F. J. Electrochem. Soc. 2011;158:A26.

10. Zhang L. L., Liang G., Ignatov A., Croft M. C., Xiong X. Q., Hung I. M., 
Huang Y. H., Hu X. L., Zhang W. X., Peng Y. L. Effect of vanadium incorporation on electrochemical performance of LiFePO4 for lithium-ion batteries. J. Phys. Chem. C. 2011;115(27):13520-13527. doi: 10.1021/jp2034906.

11. Chiang C. Y., Su H. C., Liu P. J., Hu C. W., Sharma N., Peterson V. K., Hsieh H. W., Lin Y. F., Chou W. C., Lee C. H., Lee J. F., Shew B. Y. Vanadium substitution of $\mathrm{LiFePO}_{4}$ cathode materials to enhance the capacity of LiFePO4-based lithium-ion batteries. J. Phys. Chem. C. 2012;116(46):24424-24429. doi: 10.1021/jp307047w.

12. Zhong S., Wu L., Liu J. Electrochim. Acta. 2012;74:8.

13. Wang G. X., Bewlay S., Needham S. A., Liu H. K., Liu R. S., Drozd V. A., Lee J. F., Chen J. M. Synthesis and characterization of $\mathrm{LiFePO}_{4}$ and $\mathrm{LiTi}{ }_{0.01} \mathrm{Fe}_{0.99} \mathrm{PO}_{4}$ cathode materials. J. Electrochem. Soc. 2006;153(1):A25-A31. doi: 10.1149/1.2128766.

14. Wang Z. H., Pang Q. Q., Deng K. J., Yuan L. X., Huang F., Peng Y. L., Huang Y. H. Electrochim. Acta. 2012;78:576.

15. Fang H., Liang G., Zhao L., Wallace T., Arava H., Zhang L. L., Ignatov A., Croft M. C. J. Electrochem. Soc. 2013;160:A3148.

16. Koenig G. M., Jr., Ma J., Key B., Fink J., Low K. B., Shahbazian-Yassar R., Belharouak I. Composite of $\mathrm{LiFePO}_{4}$ with titanium phosphate phases as lithium-ion battery electrode material. J. Phys. Chem C. 2013;117:21132. doi:10.1021/p4074174.

17. Huang H., Yin S. C., Kerr T., Taylor N., Nazar L. F. Nanostructured composites: A high capacity, fast rate $\mathrm{Li}_{3} \mathrm{~V} 2\left(\mathrm{PO}_{4}\right) 3 /$ carbon cathode for rechargeable lithium batteries. Adv. Mater. 2002;14(21):1525-1528. doi: 10.1002/1521-4095 (20021104) 14;21<1525:AID-ADMA1525>3.0.co;2-3.

18. Belous A. G., Novitzkaya G. N., Polyanetzkaya S. V., Gornikov Yu. I. Study of Complex Oxides of Composition La//2/////3// minus //xLi//3//xTiO//3. Russ. Izvestiya AN SSSR, Neorgan. Materialy. 1987;23(3):470-472.

19. Patoux S., Masquelier C. Lithium insertion into titanium phosphates, silicates, and sulfates. Chem. Mater. 2002;14(12):5057-5068. doi: 10.1021/cm0201798.

20. Kosova N. V., Devyatkina E. T., Slobodyuk A. B., Petrov S. A. Submicron LiFe ${ }_{1-y} \mathrm{Mn}_{\mathrm{y}}$ $\mathrm{PO}_{4}$ solid solutions prepared by mechanochemically assisted carbothermal reduction: The structure and properties. Electrochim. Acta. 2012;59(1):404-411. doi : 10.1016/j.electacta.2011.10.082.

21. Kosova N. V., Podgornova O. A., Devyatkina E. T., Podugolnikov V. R., Petrov S. A. Effect of $\mathrm{Fe}^{2+}$ substitution on the structure and electrochemistry of $\mathrm{LiCoPO}_{4}$ prepared by mechanochemically assisted carbothermal reduction. J. Mater. Chem. A. 2014;2(48):20697-20705. doi: 10.1039/c4ta04221b. 


\author{
Н. В. Косова, О. А. Подгорнова \\ Институт химии твердого тела \\ и механохимии СО РАН, \\ 630128 Новосибирск, Россия, Кутателадзе, 18 \\ E-mail:kosova@solid.nsc.ru
}

\title{
Супервалентное допирование для улучшения электрохимических характеристик $\mathrm{LiFePO}_{4}{ }^{*}$
}

Ортофосфаты LiFe ${ }_{0,9} \mathrm{M}_{0,1} \mathrm{PO}_{4}$ со структурой оливина, допированные ванадием и титаном, были получены с помощью механохимически стимулированного твердофазного синтеза с использованием высокоэнергетической планетарной мельницы АГО-2 и последующего отжига при 750 C. Показано, что ионы V и Ti не полностью замещают ионы Fe ${ }^{2+}$ в структуре LiFePO . Оставшаяся часть этих ионов участвует в образовании второй фазы с насиконоподобной структурой: моноклинной $\mathrm{Li}_{3} \mathrm{~V}_{2}\left(\mathrm{PO}_{4}\right)_{3}$ (пространственная группа $\left.P 2_{1} / n\right)$ и ромбоэдрической $\operatorname{LiTi}_{2}\left(\mathrm{PO}_{4}\right)_{3}$ (пространственная группа $R-3 c$ ). Согласно ПЭМ, средний размер частиц нанокомпозитов около 100-300 нм. ЭДС микроанализ показал, что мелкие частицы вторичных фаз сегрегированы на поверхности более крупных частиц LiFePO 4 . На зарядно-разрядных кривых LiFe ${ }_{0,9} \mathrm{M}_{0,1} \mathrm{PO}_{4}$ присутствуют плато, соответствующие LiFePO фазе. Допирование ванадием повышает устойчивость циклирования $\mathrm{LiFePO}_{4}$ и улучшает его циклируемость при высоких скоростях в большей степени, чем в случае допирования титаном.

Ключевые слова: LiFePO; супервалентное допирование; механохимическая активация; электрохимическое циклирование.

* Данная работа выполнена при частичной финансовой поддержке РФФИ (грант № 14-03-01082).

(C) Косова Н. В., Подгорнова О. А., 2015

\section{Введение}

Много попыток было предпринято, чтобы превратить плохо проводящие соединения в привлекательные электродные материалы, включая получение материала в наноразмерном состоянии, создание наноуглеродного покрытия и допирование ионами металлов [1-3]. Это позволило железофосфату лития $\mathrm{LiFePO}_{4}$ со структурой оливина, обладающему низкой электронной проводимостью и медленной диффузией лития $[3,4]$, стать перспективным катодным материалом с необходимыми электрохимическими свойствами и способствовало его внедрению в промышленность. Было показано, что диффузия ионов Li в $\mathrm{LiFePO}_{4}$ происходит преимуществен- 
но вдоль каналов [1] по криволинейной траектории. Наиболее предпочтительными собственными дефектами в $\mathrm{LiFePO}_{4}$ являются катионные антиструктурные дефекты, в которых ионы $\mathrm{Li}$ и $\mathrm{Fe}$ обмениваются местами. В соответствии с ab initio расчетами по допированию $\mathrm{LiFePO}_{4}$ низкие значения энергии характерны только для двухвалентных допантов в позициях $\mathrm{Fe}$, в то время как замещение супервалентными катионами энергетически невыгодно [5]. Между тем экспериментально было показано, что супервалентное допирование $\mathrm{LiFePO}_{4}$ в позиции Li увеличивает его электронную проводимость в $\sim 10^{8}$ раз и приводит к превосходным электрохимическим характеристикам [3]. В дальнейшем эти результаты были объяснены образованием проводящих примесных фаз. Исследованиям по повышению стабильности циклирования $\mathrm{LiFePO}_{4}$ и его циклированию при высоких скоростях до сих пор придается большое значение.

Ванадий и титан являются чрезвычайно привлекательными допантами для $\mathrm{LiFePO}_{4}$, поскольку они легко образуют соответствующие литий-металлофосфаты. Несмотря на то, что было опубликовано несколько работ по допированию $\mathrm{LiFePO}_{4}$ ванадием [612] и титаном [13-16], существует много разногласий по поводу образования твердых растворов $\mathrm{LiFe}_{1-y} \mathrm{~V}_{y} \mathrm{PO}_{4}$ и $\mathrm{LiFe}_{1-y}$ $\mathrm{Ti}_{y} \mathrm{PO}_{4}$. Некоторые авторы утверждают, что $\mathrm{V}^{3+}$ замещает $\mathrm{Fe}^{2+}$ в позициях $\mathrm{Fe}$ в пределах области растворимости $0<x<0,08$ [9] или при $x<0,1$ [7]. Сoгласно [7], предел растворимости в твердой фазе зависит от метода синтеза и температуры. Когда температу- ра синтеза увеличивается до $700{ }^{\circ} \mathrm{C}$, наблюдается понижение растворимости V и образование второй фазы $\mathrm{Li}_{3} \mathrm{~V}_{2}\left(\mathrm{PO}_{4}\right)_{3}$. Аналогично, когда производится допирование $\mathrm{LiFePO}_{4}$ ионами $\mathrm{Ti}$, то при высоком уровне допирования $(x>0,05)$ образуются примеси, такие как $\mathrm{TiP}_{2} \mathrm{O}_{7}$ и $\mathrm{LiTi}_{2}\left(\mathrm{PO}_{4}\right)_{3}$ [14]. Coобщается, что образцы $\mathrm{LiFePO}_{4}$, допированные $\mathrm{V}$ и $\mathrm{Ti}$, показывают отличную обратимую емкость и хорошую циклируемость при высоких скоростях. Тем не менее нет общей точки зрения относительно механизма этого улучшения. В большинстве предыдущих исследований катионное замещение в позициях $\mathrm{Fe}$ (позиция $\mathrm{M} 2$ ) в $\mathrm{LiFePO}_{4}$, как правило, приводит к более высоким ионной подвижности и коэффициенту диффузии $\mathrm{Li}^{+}$в связи с увеличением объема элементарной ячейки и вероятного ослабления взаимодействий Li-O. Последнее снижает сопротивление при переносе заряда и тем самым улучшает обратимость процесса литирования. Только в нескольких работах показано, что возможно катионное замещение в позициях $\mathrm{Li}$ (позиции M1), в результате чего происходит образование вакансий $\mathrm{Li}$, что увеличивает емкость $\mathrm{LiFePO}_{4}$ [11]. В связи с этим необходима разработка методов синтеза $\mathrm{LiFePO}_{4}$ с подходящим катионным допированием наряду с уменьшением размера частиц и созданием оптимального углеродного покрытия.

Целью данной работы было изучение V- и Тi-допированого $\mathrm{LiFePO}_{4}$, синтезированного механохимически стимулированным карботермическим восстановлением. 


\section{Экспериментальная часть}

$\mathrm{LiFe}_{0,9} \mathrm{~V}_{0,1} \mathrm{PO}_{4}$ и $\mathrm{LiFe}_{0,9} \mathrm{Ti}_{0,1} \mathrm{PO}_{4}$, далее обозначенные как LFVP и LFTP, были синтезированы с использованием в качестве исходных реагентов $\mathrm{Li}_{2} \mathrm{CO}_{3}$, $\mathrm{Fe}_{2} \mathrm{O}_{3}, \mathrm{~V}_{2} \mathrm{O}_{5}, \mathrm{TiO}_{2}$ и $\left(\mathrm{NH}_{4}\right)_{2} \mathrm{HPO}_{4}$. В качестве восстанавливающего и покрывающего агента использовали сажу (5 \%). Смесь исходных реагентов подвергали механической активации (МА) в высокоэнергетической планетарной мельнице АГО-2 (900 об./мин.). Отжиг мехактивированной смеси осуществляли в токе $\operatorname{Ar}$ при $750{ }^{\circ} \mathrm{C}$.

Рентгенофазовый анализ (РФА) проводили с помощью дифрактометра D8 Advance Bruker, излучение $\mathrm{CuK \alpha}$. Для структурных уточнений данных РФА использовали пакет программного обеспечения GSAS. Размер и морфологию частиц определяли с помощью просвечивающей электронной микроскопии (ПЭМ) с использованием просвечивающего электронного ми-

\section{Результаты и обсуждение}

На рис. 1 представлены дифрактограммы синтезированных образцов LFVP и LFTP, уточненные по методу Ритвельда. Видно, что они хорошо описываются двухфазной моделью: LFP c орторомбической структурой оливина (пространственная группа Pnmb) и LVP с моноклинной (пространственная группа $\left.P 2_{1} / n\right)$ или LTP с ромбоэдрической структурой (пространственная группа $R-3 c$ ). Наблюдаемые и расчетные дифрактограммы хорошо коррелируют между собой; фактор достоверности $\left(R_{w}\right)$ имеет приемлемые значения. Структура оливина LFP состоит из соединенных вершинами октаэдров $\mathrm{FeO}_{6}$, расположенных кроскопа JEM-2200 FS. Микроанализ проводили с помощью энергодисперсионного рентгеновского спектрометра EX-230 BU. Для электрохимического тестирования были приготовлены композиционные катодные материалы, состоящие из 75 вес. \% активной составляющей, 20 вес. \% проводящего углерода Super Р и 5 вес.\% связующего PVDF/NMP. Полученная суспензия затем наносилась на алюминиевую фольгу для получения рабочих электродов. Плотность приготовленных образцов составляла 2-3 мг $\times \mathrm{cm}^{-2}$, а диаметр электрода 10 мм. Рабочий электрод высушивали при $120{ }^{\circ} \mathrm{C}$. Электрохимические ячейки собирали в аргоновом боксе, используя литий в качестве анода, $1 \mathrm{M} \mathrm{LiPF}{ }_{6}$ в смеси этилен- и диметилкарбоната (1:1) в качестве электролита и стекловолоконный фильтр Whatman, Grade GF/C в качестве сепаратора.

вдоль оси $b$, которые связаны друг с другом посредством тетраэдров $\mathrm{PO}_{4}$. Моноклинная структура LVP содержит октаэдры металлов и тетраэдры фосфата, имеющие общие атомы кислорода в вершинах. Ионы лития расположены в полостях структуры [17]. Наличие цепочек полиэдров лития, соединенных вершинами вдоль оси $b$ и открытых диффузионных каналов в других направлениях, обеспечивает быстрый, изотропный ионный транспорт, подобный суперионной проводимости в соединениях со структурой NASICON. Ромбоэрическая структура LTP представляет из себя трехмерную сеть из октаэдров $\mathrm{TiO}_{6}$, соединенных 
всеми своими вершинами с тетраэдрами $\mathrm{PO}_{4}$, и наоборот, формируя так называемые «фонарики», ориентированные в том же направлении (вдоль оси c) [18]. Каналы проводимости формируются вдоль оси $c$. Результаты структурного анализа композитов, по-
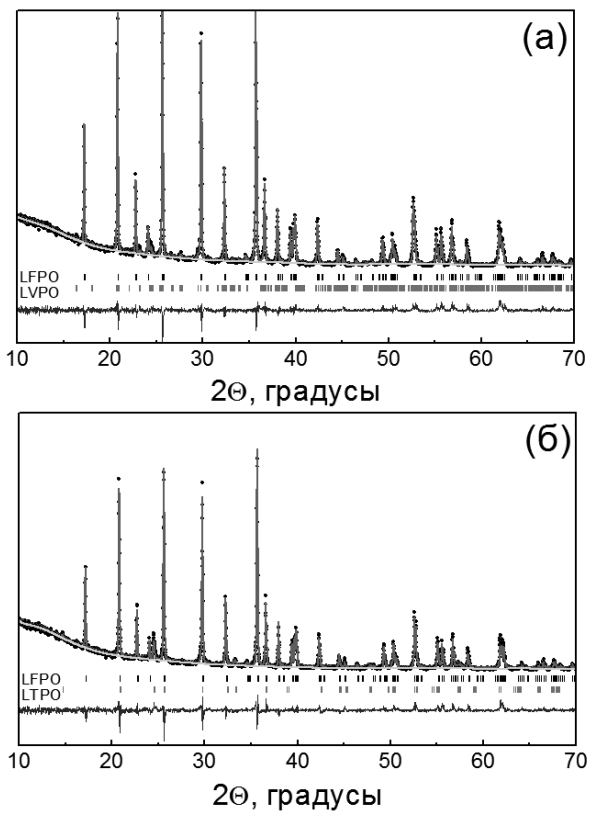

Рис. 1. Дифрактограммы V- (a) и Ті-допированного (б) $\mathrm{LiFePO}_{4}$, уточненные по методу Ритвельда лученные после уточнения дифрактограмм методом Ритвельда, представлены в табл. 1. Параметры решетки LFP в композите LFVP несколько меньше, чем у чистого LFP. Небольшие изменения параметров могут быть вызваны незначительным внедрением ионов V с меньшим ионным радиусом $\left(\mathrm{R}_{\mathrm{V} 3+}=0,64 \AA, \mathrm{R}_{\mathrm{V} 4+}=0,53 \AA\right)$ в структуpy LFP. Рассчитанное соотношение фаз LFP/LVP около 96,3/3,7 мол. \%. В композите LFTP изменения параметров решетки LFP меньше, чем в композите LFVP. Рассчитанное соотношение LFP/ LTP - 95,8/4,2 мол. \%, что свидетельствует о меньшей степени замещения $\mathrm{Ti}^{4+} / \mathrm{Fe}^{2+}$.

Вопрос о механизме внедрения супервалентных ионов в структуру LFP является дискуссионным. В соответствии с [5], этот процесс неблагоприятен для всех ортофосфатов $\mathrm{LiMPO}_{4}$. Это указывает на то, что супервалентные ионы нестабильны в кристаллической решетке $\mathrm{LiMPO}_{4}$ и вряд ли могут встраиваться в концентрациях, превышающих 3 \%. Установлено, что механизмом компенсации для супер-

Таблица 1

Результаты структурного анализа с уточнением по методу Ритвельда

\begin{tabular}{c|c|c|c|c|c}
\multirow{2}{*}{$\begin{array}{c}\text { Параметры } \\
\text { решетки }\end{array}$} & \multirow{2}{*}{ LFP } & \multicolumn{2}{|c|}{ LFVP } & \multicolumn{2}{c}{ LFTP } \\
\cline { 3 - 6 } & & LFP & LVP & LFP & LTP \\
\hline$a, \AA$ & $10,3052(1)$ & $10,2935(3)$ & $8,583(6)$ & $10,3053(3)$ & $8,491(2)$ \\
\hline$b, \AA$ & $5,9946(1)$ & $5,9886(1)$ & $8,574(6)$ & $5,9947(2)$ & $8,491(2)$ \\
\hline$c, \AA$ & $4,6833(1)$ & $4,6843(1)$ & $12,018(8)$ & $4,6828(1)$ & $20,855(9)$ \\
\hline$\square$ & & & $90,56(6)$ & & \\
\hline $\mathrm{V}, \AA^{3}$ & $289,32(1)$ & 288,76 & $884,4(7)$ & $289,29(2)$ & $1302,1(4)$ \\
\hline$R_{\text {шр }} \%$ & 6,60 & \multicolumn{2}{|c|}{8,52} & \multicolumn{2}{c}{9,29} \\
\hline$\chi^{2}$ & 1,290 & \multicolumn{2}{|c|}{2,205} & \multicolumn{2}{c}{$95,8 / 4,2$} \\
\hline $\begin{array}{c}\text { LFP/LMP } \\
\text { (мол. \%) }\end{array}$ & \multicolumn{2}{|c|}{$96,3 / 3,7$} & \multicolumn{2}{c}{}
\end{tabular}


валентных допантов является формирование вакансий $\mathrm{M}^{2+}$, в то время как изменение зарядового состояния ионов переходного металла более энергозатратно.

По литературным данным, электронное состояние ионов Fe в LFP не меняется при допировании $\mathrm{V}$ и $\mathrm{Ti}$. Авторы работ [13-15] установили, что степень окисления допированных ионов $\mathrm{Ti} 4+$, в то время как ионов $\mathrm{V}$ между 3+ и 4+ [9-11]. Замещение ионов $\mathrm{Fe}^{2+}$ ионами $\mathrm{M}^{3+}$ и $\mathrm{M}^{4+}$ в структуре LFP одновременно с образованием вакансий Li и «антиструктурных» парных дефектов может быть представлено следующими уравнениями в системе Крёгера - Винка:

$$
\begin{aligned}
& \mathrm{Li}_{\mathrm{Li}}{ }^{x} \rightarrow \mathrm{V}_{\mathrm{Li}}{ }^{\prime}+\mathrm{Li}_{i}{ }^{\prime} \\
& \mathrm{Fe}_{\mathrm{Fe}}{ }^{x}+\mathrm{Li}_{\mathrm{Li}}{ }^{x \oplus} \mathrm{Li}_{\mathrm{Fe}}{ }^{\prime}+\mathrm{Fe}_{\mathrm{Li}} \cdot \\
& 1 / 2 \mathrm{M}_{2} \mathrm{O}_{3}+3 / 2 \mathrm{Fe}_{\mathrm{Fe}}{ }^{x} \rightarrow \mathrm{M}_{\mathrm{Fe}}+1 / 2 \mathrm{~V}_{\mathrm{Fe}}{ }^{\prime \prime}+ \\
& +3 / 2 \mathrm{FeO} \\
& \mathrm{MO}_{2}+2 \mathrm{Fe}_{\mathrm{Fe}}{ }^{x} \rightarrow \mathrm{M}_{\mathrm{Fe}} \cdot \mathrm{V}_{\mathrm{Fe}}{ }^{\prime}+2 \mathrm{FeO} .
\end{aligned}
$$

Предполагается, что ионы железа могут мигрировать из положений $\mathrm{Fe}_{\mathrm{Li}}$. в вакансии $\mathrm{V}_{\mathrm{Fe}}$ ". Таким образом, основными дефектами в LFP, допированном ионами V и Ti, должны быть вакансии $\mathrm{Li}$ и ионы $\mathrm{M}^{\mathrm{n}+}$ в позициях Fe [5].

Согласно ПЭМ, образцы LFVP и LFTP состоят из наноразмерных частиц неправильной формы со средним размером около 100-300 нм, аналогично чистому LFP (рис. 2). Поверхность частиц покрыта тонким слоем углерода. Энергодисперсионный рентгеновский микроанализ подтверждает заданную концентрацию элементов в синтезированных композитах (рис. 2, a). На рис. 2, в-2 приведены индивидуальные карты распределения элементов $\mathrm{Fe}$ и V для образца LFVP при наложении с исходным изображением (рис. 2, б). Очевидно, что LVP образует более мелкие частицы, предпочтительно на поверхности более крупных частиц LFP, таким образом, вероятно, увеличивая поверхность для диффузии ионов Li в композите.

Электрохимическое поведение LFVP и LFTP изучали в диапазоне напряжений 2,5-4,3 В при скорости циклирования $\mathrm{C} / 10$. Зарядно-разрядные профили и соответствующие зависимости $\mathrm{d} Q / \mathrm{d} V$ от напряжения показаны на рис. 3. Профили, а также количество и положение окислитель-
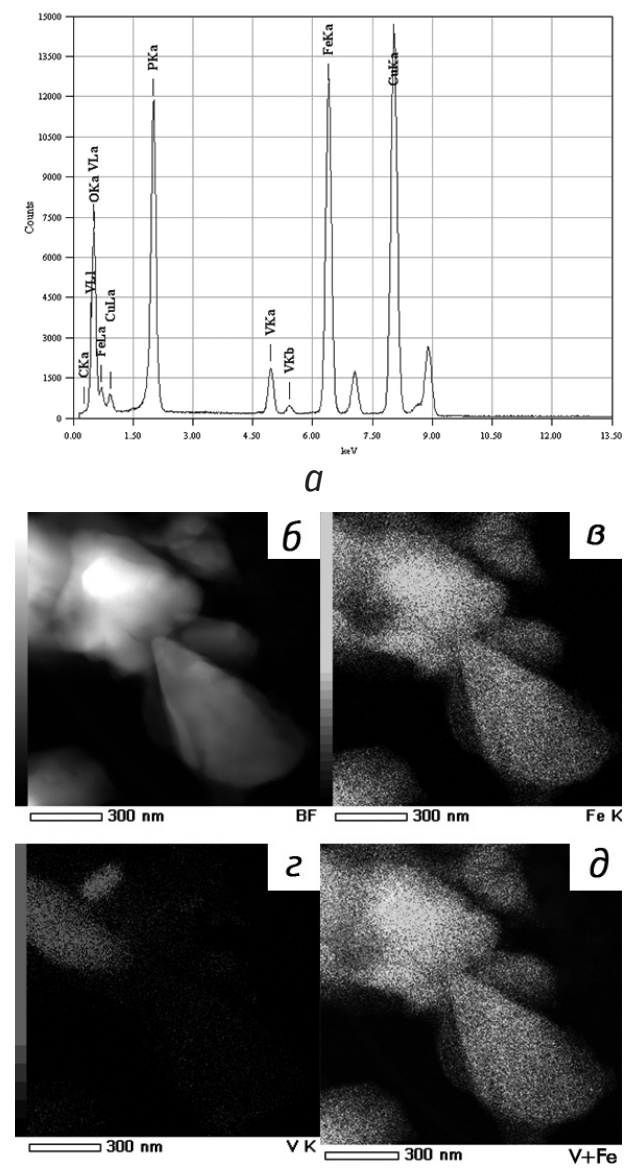

Рис. 2. EDX (a), TEM (б) и карты распределения элементов (в-д) LiFePO4, допированного ванадием 
но-восстановительных пиков согласуются с литературными данными для чистых фаз. Плато около 3,4 В относится к окислительно-восстановительной паре $\mathrm{Fe}^{2+} / \mathrm{Fe}^{3+}$, соответствующей (де)интеркаляции Li из/в LFP по двухфазному механизму. Образец, допированный V, характеризуется появлением нескольких дополнительных отчетливых плато при более высоком напряжении, которые относятся к рабочим парам $\mathrm{V}^{3+} / \mathrm{V}^{4+}$ и $\mathrm{V}^{4+} / \mathrm{V}^{5+}$ в LVP. Согласно [17], для LVP характерны три окислительных плато около 3,62; 3,70; 4,09 В при заряде до 4,3 В, соответствующие последовательным двухфазным переходам $\mathrm{Li}_{3} \mathrm{~V}_{2}\left(\mathrm{PO}_{4}\right)_{3} \mathrm{Li}_{2.5} \mathrm{~V}_{2}\left(\mathrm{PO}_{4}\right)_{3}{ }^{\bullet}$ $\mathrm{Li}_{2} \mathrm{~V}_{2}\left(\mathrm{PO}_{4}\right)_{3} \otimes \mathrm{Li}_{1} \mathrm{~V}_{2}\left(\mathrm{PO}_{4}\right)_{3}$. Очень близкое расположение окислительных и восстановительных пиков для чистого LVP при циклировании в диапазоне напряжений 2,5-4,3 В указывает на низкую степень поляризации и облегченный электронный и ионный транспорт. LFP, допированный титаном, также имеет дополнительное плато, но при более низком напряжении. Это плато соответствует рабочей паре $\mathrm{Ti}^{4+} / \mathrm{Ti}^{3+}$ в LTP. Ранее было обнаружено, что LTP может внедрять два дополнительных иона Li при напряжении $\sim 2,5$ В, соответствующем восстановлению двух ионов $\mathrm{Ti}^{4+}$ до $\mathrm{Ti}^{3+}$ [19]. Внедрение Li в LTP реализуется по двухфазному механизму. Следует подчеркнуть, что LTP служит матрицей для размещения ионов $\mathrm{Li}$, которые не могут быть внедрены обратно в структуру LFP. Отметим, что положение окислительно-восстановительных пиков на $\mathrm{d} Q / \mathrm{d} V$ зависимостях соответствует пикам для чистых LFP, LVP и LTP, свидетельствуя, что низкая степень замещения и образование композитов не оказывают заметного влияния на напряжение окислительно-восстанови-
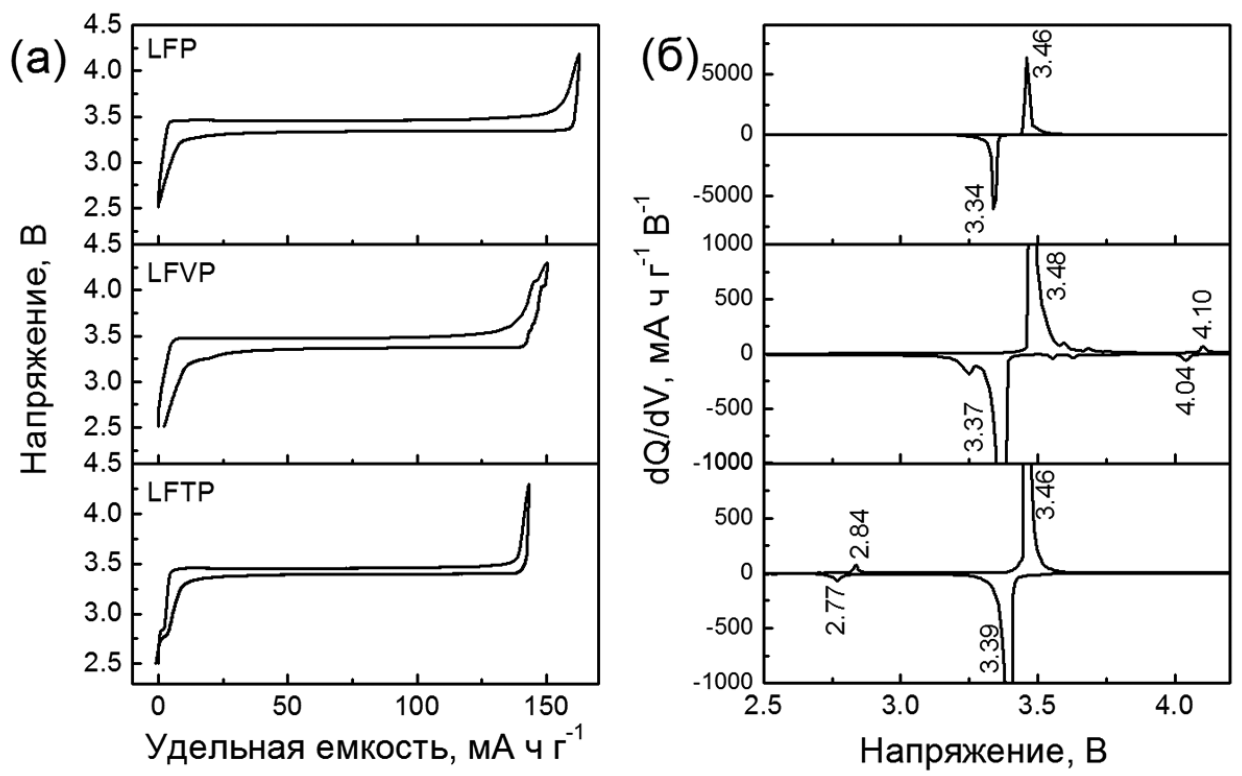

Рис. 3. Зарядно-разрядные профили (а) и зависимости $\mathrm{dQ} / \mathrm{dV}$ от напряжения (б) для чистого, $\mathrm{V}$ - и Тi-допированного LiFePO4 
тельных процессов при циклировании. С другой стороны, в случае твердых растворов со структурой оливина, например, $\mathrm{LiFe}_{1-y} \mathrm{Mn}_{y} \mathrm{PO}_{4}$ и $\mathrm{LiFe}_{1-y} \mathrm{Co}_{y} \mathrm{PO}_{4}$, окислительно-восстановительные потенциалы $\mathrm{Fe}^{2+} / \mathrm{Fe}^{3+}$ и $\mathrm{Mn}^{2+} / \mathrm{Mn}^{3+}\left(\mathrm{Co}^{2+} /\right.$ $\left.\mathrm{Co}^{3+}\right)$ постепенно понижаются/повышаются в зависимости от содержания допанта [20, 21].

На рис. 4, a, 6 представлены разрядные профили допированных образцов приразличныхскоростях, анарис. 4, 6,2зависимость удельной разрядной емкости от номера цикла при скорости
C/10 и от скорости циклирования, соответственно. Начальная разрядная емкость составляет 152 мАч $\times \Gamma^{-1}$ для LFVP и 135 мАч $\times \Gamma^{-1}$ для LFTP, однако постепенно уменьшается на последующих циклах. LFVP лучше циклирует при повышенных скоростях, чем LFTP. На наш взгляд, улучшение электрохимических характеристик LFVP является следствием присутствия фазы LVP с высокой подвижностью ионов лития и приемлемого количества точечных дефектов в структуре LFVP.

\section{Заключение}

Образцы $\mathrm{LiFePO}_{4}$, допированные ванадием и титаном, были синтезированы с помощью простого механохимически стимулированного карботермического восстановления с использованием $\mathrm{Fe}_{2} \mathrm{O}_{3}, \mathrm{~V}_{2} \mathrm{O}_{5}$ и $\mathrm{TiO}_{2}$ в качестве исходных реагентов и сажи для восстановления и создания углеродного покрытия. Было установлено, что синтезированные материалы
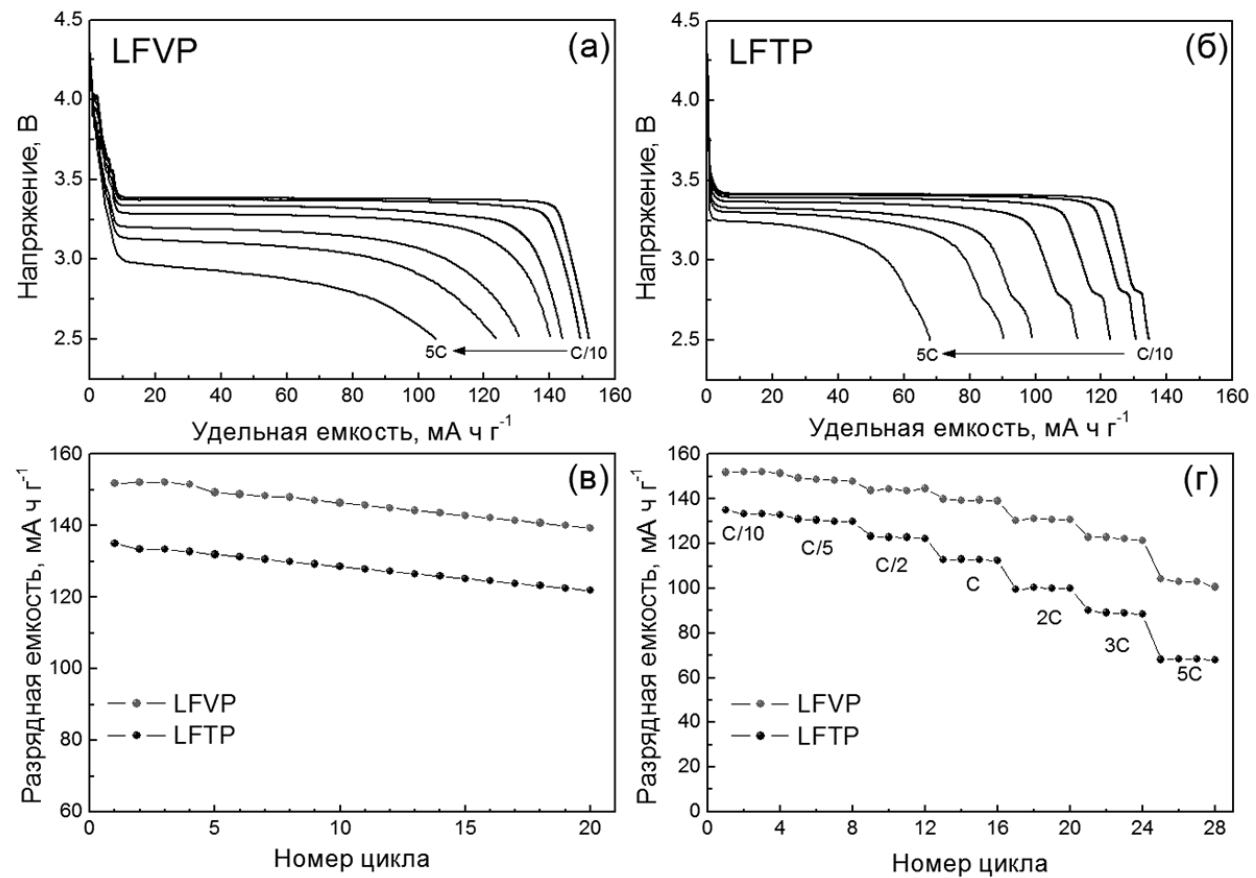

Рис. 4. Разрядные профили $(a, 6)$, зависимость разрядной емкости от номера цикла (в) и скорости циклирования (2) для $\mathrm{V}$ - и Тi-допированного $\mathrm{LiFePO}_{4}$ 
состоят из двух тонко перемешанных фаз: $\mathrm{LiFePO}_{4}$ с малой степенью замещения $\mathrm{Fe} / \mathrm{V}(\mathrm{Ti})$ и примесной фазы $\mathrm{Li}_{3} \mathrm{~V}_{2}\left(\mathrm{PO}_{4}\right)_{3}$ или $\mathrm{LiTi}_{2}\left(\mathrm{PO}_{4}\right)_{3}$. Маленькие частицы вторичных фаз сегрегированы на поверхности более крупных частиц $\mathrm{LiFePO}_{4} . \mathrm{LiFePO}_{4}$, допированный ванадием, обладает лучшей стабильностью при циклировании и циклируемостью при повышенных скоростях, чем образец, допированных титаном.
Это в большей степени связано с более высокой диффузией лития, вызванной присутствием $\mathrm{Li}_{3} \mathrm{~V}_{2}\left(\mathrm{PO}_{4}\right)_{3}$ с высокой мобильностью ионов $\mathrm{Li}$ и приемлемым количеством дефектов вследствие частичного замещения V на Fе. Увеличение числа плато и среднего напряжения интеркаляции благодаря присутствию $\mathrm{Li}_{3} \mathrm{~V}_{2}\left(\mathrm{PO}_{4}\right)_{3}$ должно иметь преимущества в улучшении циклирования ячеек с $\mathrm{LiFePO}_{4}$.

1. Yamada A., Chung S. C., Hinokuma K. Optimized $\mathrm{LiFePO}_{4}$ for lithium battery cathodes. J. Electrochem. Soc. 2001;148(3):A224-A229.

2. Ravet N., Chouinard Y., Magnan J. F., Besner S., Gauthier M., Armand M. Electroactivity of natural and synthetic triphylite. J. Power Sources. 2001;97-98:503507. doi: 10.1016/S0378-7753(01)00727-3.

3. Chung S. Y., Chiang Y. M. Microscale Measurements of the Electrical Conductivity of Doped $\mathrm{LiFePO}_{4}$. Electrochem. Solid-State Lett. 2003;6(12):A278-A281. doi: 10.1149/1.1621289.

4. Prosini P. P., Lisi M., Zane D., Pasquali M. Determination of the chemical diffusion coefficient of lithium in $\mathrm{LiFePO}_{4}$. Solid State Ionics. 2002;148(1-2):45-51. doi: 10.1016/S0167-2738(02)00134-0.

5. Fisher C. A. J., Prieto V. M. H., Islam M. S. Lithium battery materials $\mathrm{LiMPO}_{4}$ $(\mathrm{M}=\mathrm{Mn}$, transport Fe, Co, and Ni): Insights into defect association, mechanisms, and doping behavior. Chem. Mater. 2008;20(18):5907-5915. doi: 10.1021/cm801262x.

6.Wang L., Li Z., Xu H., Zhang K. J. Phys. Chem. C. 2008;112:308.

7. Omenya F., Chernova N. A., Upreti S., Zavalij P. Y., Nam K. W., Yang X. Q., Whittigham M. S. Can vanadium be substituted into $\mathrm{LiFePO}_{4}$ ? Chem. Mater. 2011;23(21):4733-4740. doi: 10.1021/cm2017032.

8. Xiang J. Y., Tu J. P., Zhang L., Wang X. L., Zhou Y., Qiao Y. Q., Lu Y. Improved electrochemical performances of $9 \mathrm{LiFePO} \cdot \mathrm{Li}_{3} \mathrm{~V}_{2}\left(\mathrm{PO}_{4}\right) / \mathrm{C}$ composite prepared by a simple solid-state method. J. Power Sources. 2010;195(24):8331-8335. doi: 10.1016/j. jpowsour.2010.06.070.

9. Ma J., Li B., Du H., Xu C., Kang F. J. Electrochem. Soc. 2011;158:A26.

10. Zhang L. L., Liang G., Ignatov A., Croft M. C., Xiong X. Q., Hung I. M., Huang Y. H., Hu X. L., Zhang W. X., Peng Y. L. Effect of vanadium incorporation on electrochemical performance of $\mathrm{LiFePO}_{4}$ for lithium-ion batteries. J. Phys. Chem. C. 2011;115(27):13520-13527. doi: 10.1021/jp2034906.

11. Chiang C. Y., Su H. C., Liu P. J., Hu C. W., Sharma N., Peterson V. K., Hsieh H. W., Lin Y. F., Chou W. C., Lee C. H., Lee J. F., Shew B. Y. Vanadium substitution of LiFePO cathode materials to enhance the capacity of $\mathrm{LiFePO}_{4}$-based lithium-ion batteries. J. Phys. Chem. C. 2012;116(46):24424-24429. doi: 10.1021/jp307047w. 
12. Zhong S., Wu L., Liu J. Sol-gel synthesis and electrochemical properties of $9 \mathrm{LiFePO}_{4}$ $\mathrm{Li}_{3} \mathrm{~V}_{2}\left(\mathrm{PO}_{4}\right)_{3} / \mathrm{C}$ composite cathode material for lithium ion batteries.Electrochim. Acta. 2012;74(15):8-15. doi: 10.1016/j.electacta.2012.03.181.

13. Wang G. X., Bewlay S., Needham S. A., Liu H. K., Liu R. S., Drozd V. A., Lee J. F., Chen J. M. Synthesis and characterization of $\mathrm{LiFePO}_{4}$ and $\mathrm{LiTi}{ }_{0.01} \mathrm{Fe}_{0.99} \mathrm{PO}_{4}$ cathode materials. J. Electrochem. Soc. 2006;153(1):A25-A31. doi: 10.1149/1.2128766.

14. Wang Z. H., Pang Q. Q., Deng K. J., Yuan L. X., Huang F., Peng Y. L., Huang Y. H. Electrochim. Acta. 2012;78:576.

[15] Fang H., Liang G., Zhao L., Wallace T., Arava H., Zhang L. L., Ignatov A., Croft M. C. J. Electrochem. Soc. 2013;160:A3148.

16. Koenig G. M., Jr., Ma J., Key B., Fink J., Low K. B., Shahbazian-Yassar R., Belharouak I. Composite of $\mathrm{LiFePO}_{4}$ with titanium phosphate phases as lithium-ion battery electrode material. J. Phys. Chem C. 2013;117:21132. doi:10.1021/p4074174.

17. Huang H., Yin S. C., Kerr T., Taylor N., Nazar L. F. Nanostructured composites: A high capacity, fast rate $\mathrm{Li} 3 \mathrm{~V} 2(\mathrm{PO} 4) 3 /$ carbon cathode for rechargeable lithium batteries. Adv. Mater. 2002;14(21):1525-1528. doi: 10.1002/1521-4095(20021104)14;21<1525::AID-ADMA1525>3.0.co;2-3.

18. Belous A. G., Novitzkaya G. N., Polyanetzkaya S. V., Gornikov Yu. I. Study of Complex Oxides of Composition La//2/////3// minus //xLi//3//xTiO//3. Russ. Izvestiya AN SSSR, Neorgan. Materialy. 1987;23(3):470-472.

19. Patoux S., Masquelier C. Lithium insertion into titanium phosphates, silicates, and sulfates. Chem. Mater. 2002;14(12):5057-5068. doi: 10.1021/cm0201798.

20. Kosova N. V., Devyatkina E. T., Slobodyuk A. B., Petrov S. A. Submicron LiFe ${ }_{1-y} \mathrm{Mn}_{\mathrm{y}} \mathrm{PO}_{4}$ solid solutions prepared by mechanochemically assisted carbothermal reduction: The structure and properties. Electrochim. Acta. 2012;59(1):404-411. doi : 10.1016/j. electacta.2011.10.082.

21. Kosova N. V., Podgornova O. A., Devyatkina E. T., Podugolnikov V. R., Petrov S. A. Effect of $\mathrm{Fe}^{2+}$ substitution on the structure and electrochemistry of $\mathrm{LiCoPO}_{4}$ prepared by mechanochemically assisted carbothermal reduction. J. Mater. Chem. A. 2014;2(48):20697-20705. doi: 10.1039/c4ta04221b. 